Maja BREZNIK, Jožica ČEHOVIN ZAJC*

\title{
PREKARIZACIJA STANDARDNEGA IN NESTANDARDNEGA ZAPOSLOVANJA V SLOVENIJI (2005-2019)**1
}

Povzetek. Namen članka je opredeliti trende in razsežnosti prekarizacije standardnega in nestandardnega zaposlovanja $v$ Sloveniji med gospodarsko depresijo in njegovo ponovno ekspanzijo. V literaturi so pojmi (ne)standardno, prekarno in neformalno delo nejasno definirani in slabo razločeni, zato jih najprej teoretsko začrtamo. Nato analiziramo spreminjanje sestave delovne sile v obdobju 2005-2019, kakor jo pokaže statistična analiza longitudinalnih mikropodatkov iz ankete Aktivno in neaktivno prebivalstvo (SURS). Ugotavljamo, da je segment prekarnega dela navzoč tako znotraj standardnega kakor nestandardnega zaposlovanja, da se prekarnost znotraj nestandardnega dela bržkone povečuje in da se s širjenjem nestandardnega dela povečuje tveganje prekarnega in neformalnega dela.

Ključni pojmi: prekarno delo, standardno delo, nestandardno delo, neformalno delo, Slovenija

\section{Uvod}

Prekarnost in prekarno delo sta prišla v akademske (znanstvene) razprave iz časopisnih polemik in političnih gibanj, ki so bila v glavnem omejena na romanske države, Francijo, Italijo in Španijo. Čeprav so ju tematizirali ugledni francoski sociologi (Robert Castel, 1996; Pierre Bourdieu, 1998; Luc Boltanski in Eve Chiapello, 1999), so ju znanstvene revije sprejele šele konec prvega desetletja 21. stoletja. Ali je to znamenje, da sta se razvila v operativni raziskovalni orodji ali celo v znanstvena koncepta?

Namen tega članka je identificirati trende in razsežnosti prekarizacije standardnega in nestandardnega zaposlovanja v Sloveniji. V prvem delu članka bova pretresli definicije standardnega, nestandardnega, prekarnega

* Dr. Maja Breznik, raziskovalka, Mirovni inštitut, Ljubljana, Slovenija; dr. Jožica Čehovin Zajc, docentka, Fakulteta za družbene vede, Univerza v Ljubljani, Slovenija.

** Izvirni znanstveni članek. DOI: 10.51936/tip.58.1.28-48

1 Raziskava je nastala s finančno pomočjo ARRS v okviru projekta SEGNED - Segmentacija nestandardnega zaposlovanja v Sloveniji (J5-9335). 
in neformalnega dela v literaturi in jih kritično analizirali. $\mathrm{V}$ drugem delu bova analizirali longitudinalne mikropodatke Ankete o delovni sili oziroma, kot se je nedavno preimenovala, Aktivnega in neaktivnega prebivalstva (v nadaljevanju ANP), da bi ugotovili spreminjanje sestave delovne sile $\mathrm{v}$ obdobju 2005-2019. Poudarek je na spreminjajočih se trendih in deležih prekarnega zaposlovanja med standardno in nestandardno zaposlenimi $\mathrm{v}$ Sloveniji. Skratka, v literaturi so omenjeni koncepti nejasno definirani in slabo razločeni, zato bova raziskovalne koncepte najprej predelali, da bova lahko potem z njimi opravili celovito analizo longitudinalnih trendov standardnega, nestandardnega, prekarnega in neformalnega zaposlovanja med gospodarsko depresijo in ponovno ekspanzijo.

V članku najprej opredeliva prekarno delo v širšem družbenem in teoretskem kontekstu glede na pojem fleksibilnosti dela in pravna razločevanja standardnega in nestandardnega dela. Nato predstaviva konceptualizacijo raznih oblik dela na podlagi merljivih kazalnikov v literaturi. Najina operacionalizacija in opisi kazalnikov, kot jih dopušča analiza obstoječih mikropodatkov ANP, so predstavljeni v poglavju metodologija. Ugotovitve predstaviva $\mathrm{v}$ poglavju o rezultatih in jih potem $\mathrm{v}$ diskusiji interpretirava.

\section{Teoretizacija prekarnosti in prekarnega dela}

Pojem fleksibilnosti označuje vrsto sprememb, tako na ravni reorganizacije podjetij in delovnega procesa kakor pri načinih zaposlovanja, ki so jih uvajali v zadnjih desetletjih 20. stoletja. Te spremembe so omogočile, da delavke in delavci delajo po skupinah in rotirajo med nalogami, kar jim je naposled samo povečalo obremenitve. Dale so jim več avtonomije in samoiniciativnosti, a hkrati tudi dodatna tveganja. Nove oblike dela so mehčale togi delovni čas za lažje usklajevanje dela z družino, toda končni rezultati so bili lažje odpuščanje in nižje mezde (Husson, 2015: 216). Fleksibilnost, vidimo, je bila rezultat sprememb v produkcijskem procesu; a vseeno se prve refleksije niso ukvarjale s produkcijskim procesom, temveč so njihovi avtorji opazovali le njegove učinke na življenja posameznikov. Ker pa so se problema lotili s konca vzročno-posledičnih povezav ali družbenih določitev, se niso otresli samoniklih (menedžerskih) ideologij. Družbene pojave, ki so jih proučevali, so zato samo "prevajali« v metafore: v družbeno negotovost (Castells, 1996), tveganje (Beck, 1999) in fluidnost (Bauman, 1999).

$\mathrm{S}$ tem pa so refleksije ostajale na izkustveni ravni, na kateri se niso mogle zares soočiti s pretenzijami nove (menedžerske) ideologije, da poveže nespravljivi tendenci. Prva se nanaša na tendenco kapitalistične produkcije, da nenehno povečuje produktivnost dela bodisi s tehnološkim razvojem produkcijskih sredstev bodisi z večjim izkoriščanjem delovne sile. Druga je odpor delavcev na te pritiske, ki se je $\mathrm{v}$ šestdesetih in sedemdesetih letih 
20. stoletja, denimo, izrazil v množičnem zavračanju odtujenega, monotonega in težkega dela, ki ga je prav v tem obdobju najbolj natančno definiral Braverman (1974).

Študije o transformaciji dela v zadnjih desetletjih 20. stoletja prikazujejo, kako so menedžerske ideologije speljale zahteve po dezalienaciji dela v svojo korist. Prvi vzvod je prišel iz Japonske z menedžersko doktrino za »optimizacijo proizvodnje«, tako imenovani toyotizem ali vitka proizvodnja (lean production po menedžerski šoli pri Massachusetts Institute of Technology) (Womack et al., 1990). Ta je metode za zviševanje produktivnosti iluzorno zlila z zahtevami po dezalienaciji dela: to, da je delavke in delavce vključevala $\mathrm{v}$ inoviranje produkcijskih procesov (z metodo kaizen) in da je reorganizirala delo za tekočim trakom $v$ delovne skupine, je prikazovala kot revolucioniranje produkcijskih odnosov, v katerih je mogoče zviševati produktivnost z emancipacijo delavcev (Pulignano et al., 2008). Drugi vzvod je bil "fleksibilna specializacija«, ki je spodbujala delavke in delavce, da se usposobijo za več delovnih nalog. Tako naj bi si izboljšali kvalifikacije, dobili več avtonomije in višje mezde. Perverzne učinke, ponotranjenje ciljev podjetja in samoizkoriščanje so avtorji ironično imenovali podjetniška kultura delavcev (Wood, 1989; Boltanski in Chiapello, 1999). Tretji vzvod so 30 "ustvarjalni grozdi« (creative clusters) v, denimo, tekstilni in strojni industriji severne Italije ali v kalifornijski elektronski industriji. K njihovemu svetovnemu uspehu naj bi prispevali industrijski odnosi, katerih posebnost je bojda bila, da podjetja ne tekmujejo drugo z drugim, temveč sodelujejo in koordinirajo razvojne dejavnosti. Zato naj bi bile prav te regije uspešnejše v tekmi s svetovno konkurenco. Analize so namesto produkcijskih grozdov odkrile mnoge plasti podizvajalcev, ki so jih vodilna podjetja ožemala in ustvarjala "ekonomijo podizvajalcev" (Harrison, 1994; Bologna, 2007; outsourcing economy v Milberg in Winker, 2013). Četrti vzvod so prispevale globalne blagovne (ali vrednostne) verige, ki decentralizirajo proizvodnjo in jo razpršijo po svetovnih regijah z najbolj ugodnimi kombinacijami produkcijskih faktorjev, med katerimi so zelo pomembne nizke mezde. Globalna reorganizacija podjetij je prispevala k pospešeni industrializaciji držav v razvoju, zato se je domnevalo, da se bo z gospodarskim napredovanjem teh držav povečala tudi blaginja zaposlenih. Kritične analize globalnih verig govorijo o neenaki in celo osiromaševalni rasti: da z večjo vključenostjo v globalne produkcijske verige podjetje ali država še ne zadrži več novo ustvarjene vrednosti. Ta nasprotno odteka v podjetja, ki so na vrhu globalnih produkcijskih verig, kar povzroča relativno siromašenje delavcev, zlasti neposrednih produkcijskih delavcev (Smichowski et al., 2019; Bair in Werner, 2015).

Pojem prekarnega dela je v odnosu do teh razprav izvršil nič manj kot spoznavni obrat, s tem da se je otresel samoniklih menedžerskih ideologij, prestavil svoj zorni kot s pogleda menedžmenta na pogled delavcev in hkrati 
blokiral možne povezave produktivnosti z dezalienacijo dela. Glavni dosežek tega pojma je, da je dosegel ta spoznavni obrat. Ni pa mogel tudi sebe predelati v znanstveni koncept (Barbier, 2005), kot se lahko prepričamo z branjem študij o prekarnosti. Poglobljeno branje pokaže, da raziskave res vključujejo pojem prekarnosti na bolj ali manj empirični ravni družbenih pojavov. Prekarnost dela se povezuje z ekonomskimi in družbenimi spremembami od sedemdesetih let naprej, ki naj bi spodbudile negotovo zaposlovanje v "slabih službah" (Kalleberg, 2011), za nizko plačilo z omejenim dostopom do socialnih in drugih zakonskih pravic (Vosko, 2010: 2; Keller in Seifert, 2013: 464), brez sedmih oblik varnosti, ki so po Mednarodni organizaciji dela sestavni elementi »dostojnega dela" (Standing, 2009, 2011). Nekateri so nasprotno hoteli dokazati, da pojem prekarnosti res ustreza znanstvenemu in teoretskemu konceptu, ki mora sčasoma nadomestiti koncept proletariata ali delavskega razreda v marksističnem pomenu (Standing, 2011; Savage et al., 2013). Vendar niso uspeli dokazati, da je pojav prekariata kakor koli omajal marksistično konceptualizacijo produkcijskih odnosov in genezo kapitalističnega produkcijskega načina, zato so bili ti poskusi brž zavrnjeni (Munck, 2013; Wright, 2016).

Težave na ravni konceptualizacije, se pravi, težave z definicijo prekarnega dela se preslikavajo na operativno raven, kjer merimo obseg in vrste prekarnega dela. Operacionalizacija prekarnosti se pogosto opira kar na pravne definicije in pravna razločevanja, na prekarno delo kot nasprotje "standardnega dela«, in se ga enači z nestandardnim ali atipičnim zaposlovanjem. Problem je, prvič, da se definicije "standardne zaposlitve« razlikujejo od države do države, zato taka operacionalizacija ni univerzalna (Barnier, 2005: 366-368). Drugič, tudi empiričnim raziskavam ni ušlo, da se prekarnost in nestandardno zaposlovanje ne prekrivata, da imajo nekateri delavci $\mathrm{v}$ nestandardnih zaposlitvah zelo dober družbeno-ekonomski položaj (Kalleberg, 2011: 76) in da so lahko nasprotno nekatere redne zaposlitve zelo prekarne (Vosko, 2010: 3). Ali, kot pravi Standing (2008: 24), "pogoji, ki so značilni za redno zaposlitev, so se sčasoma toliko poslabšali, da so dobili naravo priložnostnega dela v vsem, razen v imenu«. Zato je bilo treba opustiti normativen pogled na prekarno delo in s tem možnost, da bi ga lahko statistično zajeli samo s pravnimi kategorijami (z zaposlitvami za določen čas, $s$ krajšim delovnim časom, samozaposlovanjem, $\mathrm{z}$ agencijskim in študentskim delom, napotenimi delavci, neformalnim delom itn.). Namesto tega se moramo, kot pravi Barnier, paradoksno zadovoljiti $\mathrm{z}$ »manj zavezujočo« in precej »nejasno« definicijo prekarnega dela. Temu so se že prilagodile velike študije mednarodnih organizacij, ki so vse po vrsti sprejele stališče, da se pravne definicije oblik dela ne prekrivajo z obstojem ali neobstojem prekarnosti (gl. raziskave Evropskega parlamenta, 2016; Mednarodne organizacije dela, 2016; OECD, 2015). Podobno kot Mednarodna organizacija dela so se 
zadovoljile $\mathrm{z}$ »običajnim razumevanjem prekarnosti«, iz katerega so izluščile njegove temeljne značilnosti: (1) nizko plačilo, ki se pogosto giblje na stopnji revščine ali celo pod njo in katerega prilivi niso redni in zanesljivi; (2) negotovost zaposlitve, ker je trajanje zaposlitve negotovo in se lahko vsak čas prekine; (3) minimalni vpliv delavca, ki ne more ne individualno ne kolektivno vplivati na delovne razmere, višino mezde in intenzivnost dela; (4) manko varnosti, ker delavca ne varujejo zakoni ali kolektivni sporazumi, ki bi določali varnost in zdravje pri delu, njegove socialne pravice, ga varovali pred diskriminacijo in mu dajali druge pravice, ki jih navadno uživajo delavci v delovnem razmerju (Mednarodna organizacija dela, 2016: 18). Da bi prišli do "manj zavezujočih" in hkrati bolj rigoroznih definicij, je treba naprej opredeliti razlike med standardnim, nestandardnim in prekarnim delom, ki nam bodo omogočile izdelati operativna raziskovalna orodja.

\section{Kazalniki prekarnega dela}

Prvič, delovne razmere in dohodki nekaterih kategorij delavcev $\mathrm{v}$ standardnih zaposlitvah so lahko primerljivi s tistimi $\mathrm{v}$ nestandardnih zaposlitvah, zato se je treba vprašati, ali obstaja prekarno delo tudi med 32 standardnimi oblikami dela. Raziskava vzhodnoevropskih podjetij v elektronski industriji je pokazala, da je bil glavni dejavnik za generiranje kategorije delavcev v rednem delovnem razmerju, katerih položaj bi lahko opisali za prekaren, mezda na meji eksistenčnega minimuma ali celo pod njo (Hürtgen, 2019). Zato si bomo podrobno pogledali element plače.

Primerjava podatkov v obdobju 2005-2019 pokaže, da neto minimalna plača nobeno leto ni presegla praga tveganja revščine, ki se računa za eno leto nazaj. ${ }^{2}$ Vseeno se vidi, da se je razlika med njima začela zmanjševati po letu 2016, ko so bili iz minimalne plače izvzeti nekateri dodatki (dodatek za nočno delo, za delo v nedeljo, na praznike in dela proste dneve), po letu 2020 pa vsi dodatki. To je prispevalo k temu, da delavec in delavka lahko presežeta prag revščine, če delata ob "posebnih pogojih", za katere sta upravičena do posebnih dodatkov. Minimalno plačo lahko primerjamo še z oceno minimalnih življenjskih stroškov, ki ju je napravil Inštitut za ekonomska raziskovanja za leti 2009 in 2016. Oceni je oprl na 20\% nekmečkih gospodinjstev z najnižjimi dohodki (Stropnik et al., 2017), zato sta zares omejeni le na »biološko garantirano minimalno mezdo«, ne pa na njen »zgodovinski

2 Treba je opozoriti, da se podlagi za izračun obeh podatkov razlikujeta. Medtem ko minimalna plača predstavlja individualni dohodek iz dela, je prag tveganja revščine opredeljen s $60 \%$ mediane ekvivalentnega razpoložljivega dohodka v gospodinjstvu. Prag tveganja revščine, ki smo ga primerjali z neto minimalno plačo, je minimalni dohodek za enočlansko gospodinjstvo. Delavec ali delavka, ki prejema minimalno plačo brez katerihkoli dodatkov, je torej izpostavljen/-a revščini, če živi sam/-a ali celo v večjem gospodinjstvu brez dodatnih prihodkov. 
minimum ${ }^{3}{ }^{3} \mathrm{~V}$ tej primerjavi je minimalna neto plača dosegla oceno minimalnih življenjskih stroškov za leto 2009 šele leta 2015, oceno za leto 2016 pa je presegla šele leta 2017 za en evro, leta 2018 pa za 25 evrov - vendar ne vemo, koliko so se medtem zvišali tudi minimalni življenjski stroški, ker se ocene opravljajo vsakih pet let. ${ }^{4}$ Dohodek, ki je pod pragom minimalnih življenjskih stroškov, zagotovo pa pod pragom "zgodovinske mezde«, postavlja prejemnike minimalne plače v poseben položaj. Da bi si zvišali svoj dohodek vsaj na eksistenčni minimum, so bolj kot ostali dovzetni za izkoriščanje, saj bolj verjetno sprejemajo nadurno delo in dogovore, ki so lahko celo v nasprotju z delovnopravnimi predpisi in kolektivnimi sporazumi.

Drugič, raziskovalke in raziskovalci so problem, da vse nestandardne zaposlitve niso prekarne (se pravi, da jih ne zaznamujejo nizki dohodki, negotovost, maksimalna podreditev delavca kapitalu in pravna nezaščitenost) in da včasih te - celo kadar imajo vse značilnosti prekarnega dela - nekaterim delavcem celo ustrezajo, najprej skušali rešiti z mero "neprostovoljnostik. To pomeni, da so zanje prekarne samo tiste nestandardne zaposlitve, pri katerih so anketirane osebe izjavile, da jim nestandardno delo ne ustreza. Raziskave so potrdile (Kretsos in Livanos, 2016), da je tako "neprostovoljno« delo za določen čas, s krajšim delovnim časom ali agencijsko delo pogosto povezano s prekarnostjo, zato je ta spremenljivka postala splošno veljavno merilo za prepoznanje prekarnega dela. Med drugimi so ta kriterij sprejele tudi mednarodne organizacije (gl. prej navedene študije EP, 2016; MOD, 2016; OECD, 2015). Ta spremenljivka seveda ne more do konca pojasniti segmentacije nestandardnih oblik dela, namreč dejstva, da imajo določene kategorije delavcev v nestandardnih oblikah dela ugoden položaj na trgu dela in temu primerno visoke dohodke, zaradi česar jih ni mogoče uvrstiti med prekarne delavce. Vendar pa je dokaj zanesljiv kazalnik prekarnosti, kljub temu da verjetno podceni pojav prekarnega dela med nestandardnimi delavci.

Med temi oblikami je treba posebej omeniti »neprostovoljno delo s krajšim delovnim časom«, kar pomeni, da bi oseba želela delati polni delovni čas, ker je njeno preživetje odvisno od dohodkov iz zaposlitve, vendar ne more dobiti zaposlitve za polni delovni čas. Te okoliščine nakazujejo problem podzaposlenosti, zato v literaturi velja ta spremenljivka tudi za kazalnik podzaposlenosti (gl. raziskave EP, 2016; MOD, 2016; OECD, 2015).

3 Kot pravi Althusser: "[..KJvantitete vrednosti (mezde), ki je nujna za reprodukcijo delovne sile, ne opredeljujejo zgolj potrebe 'biološko' garantirane mezde, pač pa potrebe zgodovinskega minimuma (Marx je opozoril: angleški delavci potrebujejo pivo in francoski proletariat vino) - in ta je potemtakem spremenljiv«(Althusser, 1980: 41).

4 Podatke navajamo po Predlogu Zakona o spremembah zakona o minimalni plači (dokument št. 430-03/10-6/1), ki je bil predložen državnemu zboru 7. novembra 2018. Za dodatna pojasnila o določanju višine minimalne plače se zahvaljujemo dr. Marku Kržanu. 
Tretjič, mednarodne primerjave, ki so se osvobodile evropocentričnega pogleda na prekarno delo, so uspele ujeti pojave neformalnega dela v evropskem zaposlovanju, čeprav se jih je dotlej praviloma povezovalo samo z nerazvitimi državami. Da bi neformalno delo lahko vključili v svoja statistična opazovanja, so statistiki Mednarodne organizacije dela spremenili definicijo enote statističnega opazovanja: namesto neformalne ekonomije so začeli opazovati individualno neformalno delo. Leta 2003 je ta sprememba omogočila, da se je statistika odprla za raziskovanje neformalnega dela v razvitih državah (Williams in Lansky, 2013; Siegmann in Schiphorst, 2016). Po definiciji je neformalno delo vsako plačano delo, ki ni prijavljeno državi z namenom, da se "pogodbena partnerja izogneta plačilu davkov in socialnih zavarovanj, pa tudi delovnopravnemu varstvu, vendar v vseh drugih vidikih delo ni nezakonito (kot so nezakonite proizvodnja in preprodaja prepovedanih drog, trgovina $z$ belim blagom itn.). To pomeni, da definicija neformalnega dela ne vključuje oblik dela, ki so bodisi nezakonite bodisi niso plačane, saj gre v teh primerih za kriminalno ali nedenarno ekonomijo (Williams in Windebank, 1989: 4).

Kot primer neformalnega dela $\mathrm{v}$ razvitih državah, Williams in Lansky omenjata navidezno samozaposlene, se pravi, eno izmed oblik prikritih 34 zaposlitev (disguised employment), kot ji pravijo pri Mednarodni organizaciji dela. Prikrita zaposlitev ima po definiciji vse elemente odvisnega mezdnega dela, vendar se opravlja na drugih (napačnih in nezakonitih) pravnih podlagah (kot samozaposlitev, študentsko delo, podizvajalstvo itn.), zato da podjetje maksimalno poveča tako produkcijsko fleksibilnost kakor profite in hkrati maksimalno zmanjša stroške dela. Eurofound (2016) loči delovna razmerja te vrste kot "goljufiva dela od neformalnega dela - z utemeljitvijo, da prikrite zaposlitve imajo neko vrsto pravne podlage, čeprav napačno, medtem ko neformalno delo ni pravno formalizirano. Delavke in delavci v prikritih zaposlitvah resda uživajo omejena socialna varstva, vendar tako drobljenje kategorij otežuje globalne primerjave, zato smo prikrito zaposlitev rajši vključili v neformalno delo, ker je namen obeh izogibanje (delnega ali vsega) plačila prispevkov in delovnopravnim predpisom. Združevanje kategorij utemeljujemo tudi s tem, da imajo vse različice "neformalnega dela" poseben učinek na trg dela, s tem da večajo družbene in dohodkovne neenakosti tako znotraj neformalnega kakor formalnega zaposlovanja (Portes in Sassen-Koob, 1987; Williams in Windebank, 1989).

Če povzamemo: iz pravno definiranih skupin, kot so standardne in nestandardne zaposlitve, smo izločili statistične skupine, ki jih upravičeno imamo za prekarne: revne delavce $\mathrm{v}$ skupini tako nestandardnih kakor standardnih zaposlitev na eni strani, na drugi pa nestandardno neprostovoljno delo in neformalno delo. Ne domišljamo si, da smo s kategorijami revnih zaposlenih, neprostovoljnega in neformalnega dela izčrpali pojav 
prekarnega dela, zagotovo pa smo identificirali nekaj zanesljivih kazalnikov. Preslikujoč jih na štiri elemente prekarnosti iz prej omenjene definicije Mednarodne organizacije dela (2016: 8) vidimo, da smo z njimi zajeli vprašanje nizkega plačila, zaposlitvene negotovosti in brezpravnosti. Nismo pa zajeli vpliva delavke ali delavca na določanje delovnih razmer, višine mezde in intenzivnosti dela. Ta razsežnost se nanaša na podatke, ki jih analizirana podatkovna baza ne vsebuje, zato smo to analizo morali odložiti do takrat, ko bodo naše ugotovitve dopolnjene $z$ drugimi viri podatkov.

\section{Metodologija}

\section{Opis raziskave}

S temi kazalniki bomo v nadaljevanju analizirali obstoječe mikropodatke iz longitudinalne ankete ANP med letoma 2005 in 2019. Raziskava predstavlja najobsežnejše uradno anketiranje gospodinjstev v državi (z okoli 7.200 gospodinjstvi oziroma 15.000 oseb vsako četrtletje), ki ga Statistični urad RS (SURS) z enostavnim naključnim izborom opravlja neprekinjeno od leta 1995 naprej.

\section{Opisi statističnih kategorij}

Predstavljamo statistične kategorije standardnega, nestandardnega, prekarnega in neformalnega dela, kot smo jih identificirali v anketi ANP in v SPSS-u preračunali s kombiniranjem vprašanj in odgovorov s programskimi stavki Recode, Compute in Crosstabs. Statistične analize so bile opravljene med junijem 2019 in januarjem 2020 s programom SPSS v varni sobi SURS. Podatki so uteženi, tako da analize predstavljajo populacijske ocene v Sloveniji.

Standardno zaposleni so v delovnem razmerju (v podjetjih ali organizacijah, pri obrtnikih, kmetih in pri osebah v svobodnih poklicih) za nedoločen čas in s polnim delovnim časom ter ne delajo prek agencij za posredovanje delavcev.

Med nestandardno zaposlenimi so najprej zaposleni za določen čas in zaposleni s krajšim delovnim časom, ki delajo manj kakor 36 ur na teden. Nekateri so zaposleni tako za določen čas kot s krajšim delovnim časom. Ti se pojavljajo $v$ frekvenčnih ocenah obeh skupin, vendar smo pri računanju deležev nestandardnih zaposlitev to upoštevali, tako da smo seštevkom nestandardnih oblik odšteli podvojene enote.

Iz vseh doslej navedenih kategorij smo vzeli agencijske delavce. Ti so prikazani posebej v agencijskem delu, v katerem pa ne prikazujemo študentskega dela (dela dijakov in študentov prek študentskih servisov), ki 
ga predstavljamo kot posebno skupino. Samozaposleni pa so osebe, ki so delale v svojem (mikro)podjetju, so obrtniki, samostojni podjetniki (s. p.) ali opravljajo svobodni poklic. V razpredelnico niso vključeni samozaposleni kmetje.

Prekarno delo merimo s podatki, ki jih vsebuje anketa ANP: nizek dohodek in neprostovoljnost. Za revne zaposlene opredeljujeva tiste, ki zaslužijo manj kakor $60 \%$ povprečne neto plače. Ta kriterij sva izbrali, ker ima vse proučevano obdobje zelo podobne vrednosti kakor prag tveganja revščine, vendar brez obrata trenda v letih 2013 in 2016. Kriterij 60-odstotne povprečne plače je malenkost višji kakor prag tveganja revščine, kar lahko pojasnimo s tem, da se v dohodek všteva, denimo, tudi nadomestilo za prevoz, ki pa v resnici ni dohodek. Ločeno meriva revne standardno in revne nestandardno zaposlene. Revni nestandardno zaposleni vključujejo zaposlene za določen čas, tiste s krajšim delovnim časom in agencijske delavce, ne pa tudi samozaposlene, ker podatkovna baza ne vsebuje podatkov o njihovih dohodkih. Neprostovoljnost meriva pri dveh skupinah. Neprostovoljno zaposleni za določen čas so tisti, ki ne morejo najti stalne zaposlitve. Neprostovoljno zaposleni s krajšim delovnim časom pa delajo manj kot 36 ur, ker ne morejo najti dela s polnim delovnim časom zaradi pomanjkanja 36 dela in manjšega obsega dela.

Neformalno delo vsebuje oblike prikrite zaposlitve, ki sva jih lahko identificirali s podatki ANP: navidezno samozaposleni in prikrite zaposlitve dijakov in študentov, ki opravljajo 20 delovnih ur na teden ali več. Navidezno samozaposleni so samozaposleni, ki ne zaposlujejo drugih delavcev in so pritrdilno odgovorili na eno ali obe vprašanji: da (1) delajo samo za eno stranko in (2) v prostorih te stranke. Kot bomo videli, je treba v to skupino prišteti še "neprostovoljno delo s krajšim delovnim časom».

ANP meri tudi druge (nestandardne) oblike dela, ki jih nisva vključili v razpredelnico, da bi bila predstavitev preglednejša in ker jih opravlja manjši delež delovno aktivne populacije. To so pogodbeno delo, delo za neposredno plačilo, javna dela in vajeništvo. Večja kategorija, ki sva jo izpustili, so "pomagajoči družinski člani«, ki pomagajo pri »družinski pridobitni dejavnosti«, ker pa praviloma ne prejemajo plačila za svoje delo, sensu stricto niso odvisne zaposlitve in sva jih vzeli iz prikaza. Zato deleže zaposlitev (standardnih, nestandardnih itn.) prikazujeva kot odstotek vseh delovno aktivnih, ki vključuje pogodbeno delo, delo za neposredno plačilo, vajeništvo in javna dela, čeprav jih nisva prikazali v razpredelnici, ne vključuje pa pomagajočih družinskih članov. Ti namreč večinoma ne prejemajo plačila za svoje delo, zato ta segment pravzaprav sodi v nedenarno ekonomijo in ne bi bilo ustrezno, če bi ga primerjali z drugimi oblikami (odvisnega mezdnega) dela. Dodati je še treba, da se je število pomagajočih družinskih članov močno zmanjšalo: leta 2005 je štelo 50 tisoč oseb, leta 2019 pa le še 16 tisoč oseb. 


\section{Rezultati: pregled standardnega, nestandardnega, prekarnega in neformalnega zaposlovanja v obdobju 2005-2019}

V tem poglavju predstavljava rezultate analize, obseg in dinamike standardnega in nestandardnega zaposlovanja ter prekarnega in neformalnega dela v Sloveniji med letoma 2005 in 2019. Podrobnejši podatki so predstavljeni v tabeli 1.

\section{Standardno in nestandardno delo}

Osnovni izračuni mikropodatkov ANP kažejo, da je standardno zaposlovanje še vedno prevladujoča oblika zaposlovanja v Sloveniji. Število standardno zaposlenih je doseglo prvi vrh leta 2008 s 682 tisoč zaposlenimi. V letih recesije se je zniževalo in leta 2014 doseglo najnižje število 588 tisoč. Potem se je z gospodarsko rastjo spet povečevalo in leta 2019 doseglo rekordno število 688 tisoč standardno zaposlenih. Gibanje standardnega zaposlovanja pa se (upoštevajoč kratka ciklična nihanja) pokaže nekoliko drugače, če ga primerjamo v deležu vseh delovno aktivnih brez pomagajočih družinskih članov.

Delež nestandardnih oblik dela, ki jih prikazujeva v razpredelnici (zaposlenih za določen čas, zaposlenih s krajšim delovnim časom, prek agencijskega dela, študentskega dela in samozaposlovanja), pa se je v tem obdobju ves čas povečeval, če zanemarimo manjša nihanja. Samo v zadnjem konjunkturnem letu 2019 opazimo znižanje deleža.

Približno slaba desetina vseh delovno aktivnih dela za določen čas. Medtem ko je število zaposlitev za določen čas v proučevanem obdobju 2005-2019 nihalo (s 100 tisoč leta 2007 se je v letih 2009 in 2013 zmanjšalo na okoli 80 tisoč, a se je vsakič povečalo na prejšnjo raven okoli 90 tisoč in se v zadnjem letu zmanjšalo na 75 tisoč), pa ravno nasprotno velja za zaposlovanje $s$ krajšim delovnim časom. V obdobju 2005-2019 se je skoraj podvojilo (s 24 na 46 tisoč) in predstavlja okoli $5 \%$ vseh delovno aktivnih. Pri tem velja omeniti, da se je do leta 2018 skoraj podvojilo tudi število zaposlenih za določen čas, ki so hkrati zaposleni s krajšim delovnim časom, s 6 na 11 tisoč oseb, leta 2019 pa se je zmanjšalo na 7,5 tisoč.

Agencijsko delo, ki je leta 2005 predstavljalo približno odstotek vseh delovno aktivnih (oziroma 10 tisoč oseb, v času krize pa najmanj 6,6 tisoč oseb), se je do leta 2018 skoraj podvojilo na 1,9\% (oziroma 18 tisoč oseb, vendar je leta 2019 spet padlo na 12,6 tisoč). Študentsko delo ves čas opravlja $3 \%$ vseh delovno aktivnih (okoli 30 tisoč oseb), med letoma 2007 in 2011 celo $4 \%$, največ pa leta 2008, ko je delalo 42 tisoč dijakov in študentov.

Samozaposlovanje se je v proučevanem obdobju postopoma povečevalo s 7,3\% leta 2005 (skupaj okoli 66 tisoč oseb) na 10,6\% delovno aktivnih 


\begin{tabular}{|c|c|c|c|c|c|c|c|c|c|c|c|c|c|c|c|c|}
\hline \multirow{4}{*}{ 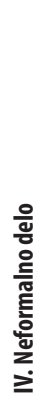 } & 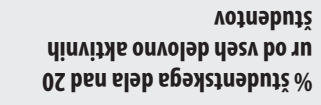 & ì & ڤั่ & o̊ & 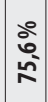 & 离 & $\frac{a}{2}$ & 高 & $\begin{array}{l}\text { å } \\
\infty \\
0 \\
0\end{array}$ & $\begin{array}{l}\text { å } \\
\text { के }\end{array}$ & 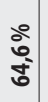 & $\begin{array}{c}\stackrel{0}{2} \\
\text { \& }\end{array}$ & 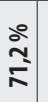 & ลें & $\frac{\circ}{0^{\circ}}$ & i̊ \\
\hline & 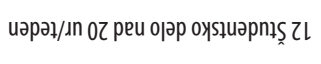 & $\infty_{\infty}^{\infty}$ & ڤ్ & 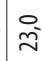 & $\tilde{\approx}$ & m. & $\begin{array}{l}\stackrel{2}{2} \\
\infty \\
\infty\end{array}$ & $\underset{2}{\sigma}$ & $\approx$ & $\bar{\lambda}$ & $\stackrel{0}{\mathbb{N}}$ & ฟे & ลे & s. & $\stackrel{a}{\doteqdot}$ & $\stackrel{\infty}{\infty}$ \\
\hline & 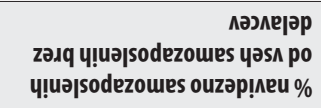 & $\stackrel{\circ}{\circ}$ & 离 & $\stackrel{\circ}{\stackrel{2}{n}}$ & $\begin{array}{c}\stackrel{\circ}{2} \\
\tilde{\sim}\end{array}$ & $\frac{i}{i}$ & ¿̊̀. & $\begin{array}{l}\infty \\
\infty \\
\infty \\
\infty\end{array}$ & $\stackrel{\substack{\circ \\
\stackrel{0}{=}}}{=}$ & & & & & & & \\
\hline & 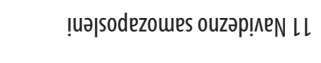 & $\stackrel{\Im}{a}$ & $\stackrel{0}{m}$ & $\stackrel{\circ}{i}$ & $\stackrel{\infty}{m}$ & $\stackrel{g}{m}$ & $\stackrel{\Xi}{=}$ & $\bar{o}$ & مे & & & & & & & \\
\hline \multirow{6}{*}{ 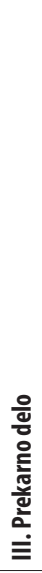 } & 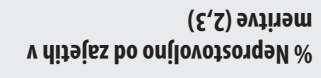 & $\begin{array}{l}\stackrel{0}{0} \\
\infty \\
\stackrel{0}{0}\end{array}$ & $\begin{array}{l}\text { aे } \\
\text { ò }\end{array}$ & $\stackrel{\text { in }}{\stackrel{2}{n}}$ & \begin{tabular}{l}
$\stackrel{0}{0}$ \\
\multirow{0}{0}{}
\end{tabular} & $\begin{array}{l}\text { o̊ } \\
\text { fó }\end{array}$ & $\begin{array}{l}2 \\
\infty \\
0 \\
0 \\
0\end{array}$ & $\begin{array}{l}\stackrel{\circ}{0} \\
\dot{0} \\
\phi^{\circ}\end{array}$ & $\begin{array}{l}8 \\
0 \\
0 \\
9\end{array}$ & $\begin{array}{c}\stackrel{0}{m} \\
\tilde{n}\end{array}$ & $\begin{array}{l}\stackrel{0}{2} \\
\bar{n}\end{array}$ & 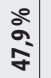 & $\frac{\circ}{\circ}$ & ֻั & ڤે & 竞 \\
\hline & 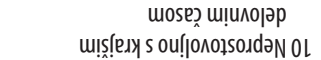 & oे & $\hat{m}$ & $\stackrel{a}{ \pm}$ & $\stackrel{-1}{=}$ & 可 & $\stackrel{l}{=}$ & å & के & {$\left[\begin{array}{ccc}\tilde{c} \\
\infty\end{array} \mid\right.$} & ㅇ. & $\therefore$ & $\tilde{n}$ & $\hat{\sigma}$ & 8 & 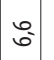 \\
\hline & 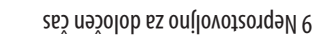 & 望 & బ̌ & 8 & mo & $\begin{array}{l}0 \\
6 \\
0\end{array}$ & 亏ેे & $\underset{\sim}{\sim}$ & $\frac{2}{\xi}$ & $\frac{2}{i n}$ & $\underset{\sigma}{\sigma}$ & 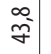 & 亏े & 总 & 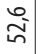 & $\stackrel{0}{\circ}$ \\
\hline & 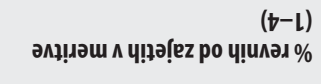 & & $\stackrel{2}{a}$ & 产 & 紊 & $\frac{1}{\dot{2}}$ & $\begin{array}{l}\stackrel{\circ}{a} \\
=\end{array}$ & $\frac{2}{=}$ & 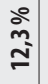 & $\frac{\therefore}{m}$ & 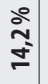 & 今 & & & & \\
\hline & 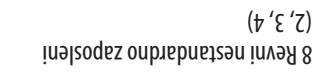 & - & $\stackrel{\infty}{m}$ & fे & $\xi^{2}$ & 齐 & $\stackrel{\circ}{9}$ & $\stackrel{\sim}{m}$ & 官 & $\tilde{m}^{2}$ & 兽 & $\stackrel{n}{F}$ & & & & \\
\hline & 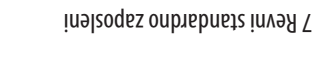 & - & సे & 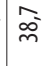 & $\hat{\sigma}$ & 䒚 & 或 & $\mid$ & $\tilde{\tilde{n}}$ & 官 & 总 & nू. & & & & \\
\hline \multirow{6}{*}{ 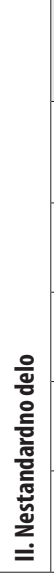 } & 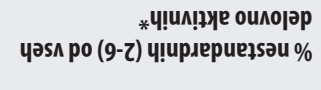 & $\frac{\text { के }}{\circ}$ & $\begin{array}{l}\text { oे } \\
\infty \\
\text { के }\end{array}$ & o̊ & 竞 & o̊ & 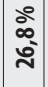 & $\begin{array}{l}\stackrel{0}{0} \\
\hat{a}\end{array}$ & $\begin{array}{l}\text { ปें } \\
\text { ปें }\end{array}$ & $\frac{\therefore}{i}$ & 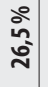 & $\begin{array}{l}\stackrel{0}{ \pm} \\
\dot{\sim}\end{array}$ & 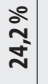 & 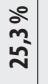 & 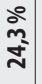 & 竞 \\
\hline & !̣əasodezoures 9 & ฮี & $\frac{5}{2}$ & $\tilde{\sigma}$ & 官 & $\underset{j}{a}$ & $\left|\begin{array}{c}n \\
\infty \\
\infty\end{array}\right|$ & $\widehat{\mid c}$ & 痛 & के & $\frac{0}{\infty}$ & ño & 茖 & $\hat{n}$ & $\stackrel{\sim}{\Sigma}$ & $\mid$ \\
\hline & 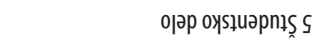 & $\stackrel{m}{\approx}$ & $\widehat{\bar{m}}$ & $\stackrel{0}{m}$ & $\hat{\bar{m}}$ & ì & i̊ & $\widehat{\bar{c}}$ & 竞 & 足 & $\begin{array}{c}0 \\
\dot{m}^{\circ}\end{array}$ & $\begin{array}{c}0 \\
i \\
m\end{array}$ & $\stackrel{\Im}{\Im}$ & $\underset{m}{\approx}$ & $\underset{m}{\approx}$ & 品 \\
\hline & 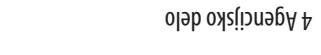 & $\stackrel{q}{\simeq}$ & $\stackrel{2}{=}$ & $\stackrel{\infty}{\beth}$ & a & $\stackrel{\Xi}{=}$ & $\therefore$ & $\stackrel{0}{\infty}$ & $\stackrel{0}{=}$ & $\hat{\sigma}$ & $\approx$ & $\stackrel{\circ}{\circ}$ & $\approx$ & 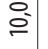 & $\widehat{\infty}$ & $\stackrel{\infty}{\infty}$ \\
\hline & 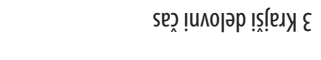 & ר̌ & só & 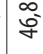 & $\overline{\tilde{\gamma}}$ & 夈 & 㤐 & $\stackrel{\stackrel{\sim}{2}^{2}}{m}$ & 点 & 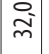 & 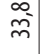 & ले & $\stackrel{\curvearrowright}{\AA}$ & 总 & ذે & $\stackrel{m}{d}$ \\
\hline & 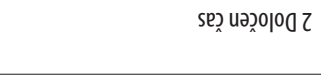 & 总 & $\begin{array}{l}0 \\
8\end{array}$ & $\stackrel{\infty}{\kappa^{-}}$ & $\widehat{\infty}$ & 亏े & $\left|\begin{array}{l}0 \\
\infty \\
\infty\end{array}\right|$ & $\begin{array}{l}\stackrel{\Omega}{\Sigma} \\
\hat{\Sigma}\end{array}$ & $\bar{\infty}$ & $\frac{m}{\sigma}$ & $\bar{\infty}$ & $\frac{\sigma}{\infty}$ & $\widetilde{\Omega}$ & $\begin{array}{l}\infty \\
\stackrel{0}{0}\end{array}$ & $\begin{array}{c}\stackrel{2}{\infty} \\
\infty\end{array}$ & $\widehat{\tilde{\sigma}}$ \\
\hline \multirow{3}{*}{ 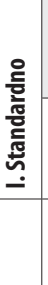 } & 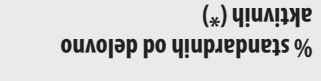 & 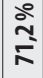 & 离 & 瓷 & 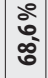 & ণ̊ & $\begin{array}{c}\stackrel{0}{2} \\
\bar{s} \\
0\end{array}$ & $\begin{array}{l}\text { วิ } \\
\text { ò }\end{array}$ & 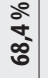 & $\begin{array}{l}0 \\
0 \\
0 \\
0\end{array}$ & $\begin{array}{l}0 \\
0 \\
0 \\
0 \\
0\end{array}$ & $\begin{array}{l}\stackrel{0}{\hat{2}} \\
\hat{2}\end{array}$ & 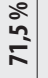 & $\begin{array}{l}\text { वे } \\
\text { वेt }\end{array}$ & $\begin{array}{l}\text { 今े } \\
\text { হి }\end{array}$ & $\begin{array}{c}\stackrel{0}{m} \\
\bar{k}\end{array}$ \\
\hline & 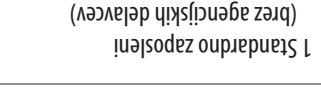 & ma & $\stackrel{\infty}{\mathcal{f}}$ & 冚 & ָิ) & 离 & $\mid \begin{array}{l}- \\
\infty \\
\mathscr{p}^{-}\end{array}$ & 怘 & క్ర & $\widehat{\hat{8}}$ & ๙ิ & 褐 & $\frac{a}{\bar{g}}$ & 은 & $\begin{array}{l}\infty \\
\stackrel{-}{G} \\
\end{array}$ & $\begin{array}{c}\tilde{p} \\
\tilde{f} \\
\tilde{F}\end{array}$ \\
\hline & 0137 & $\check{\nu}$ & $\stackrel{\infty}{\grave{2}}$ & స్ & ¿ั & $\stackrel{n}{\grave{n}}$ & $\stackrel{+}{\grave{d}}$ & $\stackrel{m}{\bar{\sigma}}$ & స్ & $\overline{\mathrm{d}}$ & 을 & ఏे & ڤ్రి & ఫ્స & ¿્ర & 岂 \\
\hline
\end{tabular}


Dodatna pojasnila $\mathrm{k}$ razpredelnici:

I. Standardno zaposleni: Niso všteti zaposleni za nedoločen čas, ki so bodisi agencijski delavci bodisi delajo s krajšim delounim časom. Ti so prikazani na strani nestandardnih zaposlitev.

II. Nestandardno delo: Podatki o zaposlenih za določen čas (2) in s krajšim delounim časom (3) ne vključujejo agencijskih delavcev. Ti so prikazani kot agencijski delavci (4) ne glede na tip pogodbe o zaposlitvi. Dobra polovica samozaposlenih ne zaposluje drugih delavcev - od te osnove se merijo odstotki navidezno samozaposlenih.

III.Prekarno delo: Odstotki tako "revnih delavcev « kakor "neprostovoljnega dela « so deleži od skupin, ki sta bili pri vsaki kategoriji zajeti v meritve: seštevek 1, 2, 3 in 4 pri "revnih delavcih" in seštevek 2 in 3 (seveda zmanjšan za število oseb, ki so istočasno v obeh skupinah) pri "neprostovoljnem delu«.

* Odstotki standardno in nestandardno zaposlenih so izračunani od vseh delovno aktivnih, ki smo jim odšteli pomagajoče družinske člane. Pri izračunu odstotkov za nestandardno zaposlene smo podvojene, tj. tiste, ki delajo sočasno po dveh kriterijih (za določen čas in s skrajšanim delovnim časom), predhodno odšteli. Njihovo število se je v proučevanem obdobju gibalo med okoli 5.000 in 11.000. Podrobnejši podatki so na voljo pri avtoricah.

leta 2018 (skupaj 101 tisoč oseb). Več kot polovica samozaposlenih (leta $200554 \%$, leta 2018 pa že 64\%) ne zaposluje drugih delavcev. Med samozaposlene sicer sodijo tudi kmetje, katerih delež se je zmanjšal s $3 \%$ na $2 \%$ vseh delovno aktivnih (ali s 30 na 20 tisoč oseb).

\section{Prekarno delo}

V prekarno delo uvrščava revne delavce, ki zaslužijo do $60 \%$ povprečne neto plače. Podatkovna baza vsebuje podatke samo za obdobje od leta 2009 do leta 2018. Število revnih standardno zaposlenih se je v tem obdobju zmanjšalo za polovico: v obdobju 2009-2018 s 14,5 (ali 95 tisoč oseb) na 5,7\% vseh standardno zaposlenih (ali 37 tisoč oseb). Nasproten trend je med nestandardnimi delavci. Med tistimi, ki so zaposleni za določen čas, s krajšim delovnim časom ali delajo prek agencije za posredovanje delavcev, se je do leta 2013 število revnih zmanjševalo (z 41,5 na 32,5 tisoč oseb ali, izraženo v odstotkih, s 35,5 na 28,5\% vseh prej omenjenih skupin). Po letu 2013 se je njihovo število začelo zviševati in že dve leti pozneje preseglo izhodiščno točko: leta 2017 je bilo revnih 45 tisoč oseb, kar ob povečanem številu nestandardno zaposlenih znese 35\%. Leta 2019 se pokaže upad revnih nestandardno zaposlenih za določen čas, s krajšim delovnim časom ali prek agencije za posredovanje dela na 39,8 tisoč oseb. Med zaposlenimi za določen čas je »reven"vsak četrti, med agencijskimi delavci skoraj vsak tretji, med zaposlenimi s krajšim delovnim časom pa več kot polovica. ANP ne vsebuje podatkov o dohodkih samozaposlenih oseb.

Treba je omeniti še skupino dijakov in študentov, ki kljub veliki delovni aktivnosti dosegajo nizke dohodke: kar $90 \%$ ima dohodke nižje od 60-odstotne povprečne plače in so »revni delavci«, čeprav tretjina od njih opravlja delo za polni delovni čas. V preglednici niso prikazani. 
Drugo merilo prekarnosti je "neprostovoljnost«. Med zaposlenimi za določen čas jih je približno polovica ali več, ki bi želeli delati za nedoločen čas, vendar ne morejo najti stalne zaposlitve. Leta 2014 je bil delež neprostovoljno zaposlenih za določen čas največji, blizu 70\%. Zadnji leti 2018 in 2019 se je njihovo število zelo zmanjšalo, vendar je sorazmerno večje število tistih, ki so odgovorili, da delajo za določen čas po »individualni (t.i. menedžerski) pogodbi o zaposlitvi«. Med zaposlenimi s krajšim delovnim časom je od dve do tri desetine "neprostovoljnih", ker ne morejo najti dela s polnim delovnim časom. S povečevanjem števila zaposlenih s krajšim delovnim časom se je hkrati skoraj podvojilo tudi število tistih, ki neprostovoljno opravljajo delo s krajšim delovnim časom.

\section{Neformalno delo}

Med samozaposlenimi (ki ne zaposlujejo delavcev in niso kmetje) vsak četrti dela samo za eno stranko in/ali v prostorih te stranke, se pravi, zelo verjetno kot prikrito zaposlen. Njihovo število se je po letu 2012, odkar anketa meri ta pojav, povečevalo: $s$ 17,8\% vseh samozaposlenih $v$ izhodiščnem letu (ali 8,8 tisoč oseb) na 21\% leta 2018 (ali 13,5 tisoč oseb), leta 2019 pa upadlo

40 na $18,9 \%$ (12,4 tisoč oseb). Leta 2016 je bil v prikriti zaposlitvi skoraj vsak peti samozaposleni (23,9\% ali 14 tisoč oseb). Približno polovica (med 40 in $55 \%$ ) navidezno samozaposlenih je prikrito zaposlenih po obeh kriterijih.

Med prikrite zaposlitve umeščamo tudi študentsko delo, ki ga opravljajo študentke in študenti ob študijskih obveznostih v obsegu 20 ur na teden in več. Teh je približno 20 tisoč ali dve tretjini delovno aktivnih študentov (delež variira med 64,6 in 75,6\%). To pomeni, da mnogim delovno aktivnim študentom primarna dejavnost ni študij, temveč delo za plačilo. Vsa proučevana leta približno tretjina delovno aktivnih študentov dela s polnim delovnim časom - več kot 36 ur na teden.

\section{Druge (nestandardne) oblike dela}

ANP vsebuje tudi druge nestandardne oblike dela. V razpredelnico jih nisva vključili zaradi preglednosti, pa tudi ker niso množične in ne bi spremenile splošnih tendenc. Pogodbeno delo je od leta do leta opravljalo med pol odstotka in dobrim odstotkom vseh delovno aktivnih. Delo za neposredno plačilo opravlja vse manj ljudi, leta 2018 samo še $0,1 \%$ vseh delovno aktivnih. Enako se je močno zmanjšalo število zaposlitev prek javnih del in vajencev: leta 2018 je javna dela opravljalo le še $0,15 \%$ in vajeniška manj kot $0,1 \%$ vseh delovno aktivnih. 


\section{Diskusija}

S časovnimi serijami smo lahko preverili, kakšno težnjo imajo pojavi, ki smo jih identificirali, katere oblike dela naraščajo, koliko se gospodarska ekspanzija po letu 2014 opira na nestandardno, prekarno in neformalno zaposlovanje delavcev.

Z obdobjem, ki smo ga zajeli, smo ujeli tudi učinke reforme trga dela v letu 2013. Ključna rezultata reforme, ki so jo podpirali vsi socialni partnerji, sta bila liberalizacija režima odpuščanja na eni strani in omejevanje nekaterih oblik nestandardnega dela na drugi (Stanojević in Furlan, 2018: 17; gl. tudi Bembič, 2018). Doslejšnje analize niso prinesle nedvoumnega odgovora na vprašanje, ali je reforma dosegla zastavljene cilje. Prve raziskave so zaznale desegmentacijske učinke, določeno zmanjševanje deleža zaposlitev za določen čas v primerjavi z zaposlitvami za nedoločen čas pri novih zaposlitvah (UMAR in MDDSZ, 2015; Kajzer, 2015), toda poznejše analize (UMAR, 2016; 2017) so pokazale, da so bili ti učinki samo kratkotrajni. Vodopivec, Laporšek in Vodopivec (2016) so z drugačno metodo prišli do nasprotnega sklepa, da je reforma dosegla svoj cilj. Ker zdaj imamo podatke za daljše obdobje, lahko z večjo zanesljivostjo preverimo učinke reforme. Ob tem smo lahko preizkusili še tezo Mednarodne organizacije dela, ki pravi, da odpravljanje negativnih učinkov prekarizacije z reformami običajno ni uspešno (MOD, 2916: 218-219).

Kaj kažejo rezultati naše študije? Vse od leta 2014 naprej (v obdobju gospodarske ekspanzije) se je število standardno zaposlenih zviševalo vse do ravni, ko je celo preseglo prej največje število leta 2008. Tudi njihov delež v skupini delovno aktivnih se je v zadnjem letu 2019 skoraj izravnal z obdobjem pred recesijo ( $71,2 \% \mathrm{v}$ primerjavi z $71,5 \%$ leta 2008$)$. Vendar nas to ne sme zavesti. V obdobju 2005-2008, ko je bila povprečna stopnja BDP-ja pozitivna (v povprečju $5 \%$ ), je delež standardno zaposlenih nihal okoli povprečja 70,5\%. V obdobju 2009-2013, ko je bila povprečna letna rast BDP-ja negativna $(-1,78 \%)$, je bil povprečni delež standardno zaposlenih $68,8 \%$. V naslednjem obdobju 2014-2019, ko je bila povprečna rast BDP-ja pozitivna (3,2\%), se je povprečni delež standardno zaposlenih celo znižal na 68,4\%, čeprav se je le konjunkturnega leta 2019 delež standardno zaposlenih približal stanju pred ekonomsko recesijo.

Podobno primerjavo lahko naredimo tudi za nestandardne zaposlitve (se pravi, najpogostejše oblike, predstavljene $\mathrm{v}$ razpredelnici) in opazimo ravno nasproten trend. Medtem ko je bil v letih recesije njihov povprečni delež $26,2 \%$, se je v letih gospodarske ekspanzije zvišal že na $27,8 \%$, kar je precejšnje povečanje glede na obdobje med letoma 2005-2009, ko je bil ta delež še $24,4 \%$. Potemtakem lahko sklepamo, da ne gospodarska ekspanzija ne reforma ni uspela zmanjšati deleža najpogostejših oblik nestandardnega zaposlovanja. 
Med nestandardno zaposlenimi, če zanemarimo nihanja iz leta v leto, se v obdobju ni bistveno spremenilo število zaposlitev za določen čas in študentskih del (razen zmanjševanja v zadnjih dveh letih). Nasprotno se je v proučevanem obdobju precej povečevalo število zaposlenih s krajšim delovnim časom, agencijskih delavcev 5 in samozaposlenih. Skupini zaposlenih s krajšim delovnim časom in samozaposlenih sta se od leta 2005 do 2019 skoraj podvojili, agencijsko delo nasprotno zelo niha - leta 2018 je skoraj podvojilo svojo izhodiščno vrednost, vendar se že naslednje leto precej znižalo.

Toda, kot sva razložili v uvodu, upoštevati moramo, da se vse nestandardne zaposlitve nujno ne prekrivajo s prekarnim delom. Nekatere kategorije delavcev v nestandardnih oblikah dela lahko zavestno izbirajo zaposlitve te vrste, ker imajo ugoden položaj na trgu dela, s tem pa tudi relativno visoke dohodke, ali ker jim omogočajo lažje usklajevanje dela z družinskimi in drugimi obveznostmi. To nakazuje na segmentacijo nestandardnega zaposlovanja: znotraj iste pravne oblike so samo nekatere prekarne tudi po vsebini.

V operacionalizaciji konceptov smo, glede na možnosti, ki jih je ponujala podatkovna baza ANP, prekarno delo določili z dvema spremenljivkama. Prva je denarno nadomestilo za opravljeno delo, ki je v literaturi, kot smo že povedali, ključna značilnost prekarnih oblik dela. Drugo spremenljivko smo imenovali »neprostovoljno nestandardno delo«.

Vseh neprostovoljno zaposlenih za določen čas in s krajšim delovnim časom je skupaj dobra polovica. Med zaposlenimi za določen čas je bilo pretekla leta povprečno $60 \%$ tistih, ki ne morejo najti stalne zaposlitve, toda $\mathrm{v}$ zadnjih dveh letih so anketiranci in anketiranke kot razlog za delo za določen čas pogosteje navajali »individualne pogodbe«. Med zaposlenimi $s$ krajšim delovnim časom je bilo ves čas povprečno $28 \%$ tistih, ki ne morejo najti zaposlitve za polni delovni čas. Veliko zaposlenih s krajšim delovnim časom prejema nizke dohodke, a ker ta dohodek lahko prištejejo drugim dohodkom v družini, niso nujno eksistenčno ogroženi. Skupina »neprostovoljno zaposlenih s krajšim delovnim časom«, ki nima dostopa do zaposlitve za polni delovni čas, pa je lahko eksistenčno neposredno ogrožena zaradi sorazmerno nižjega dohodka in posredno z neustrezno pokojninsko varnostjo, saj je zavarovana samo sorazmerno z delovnim časom, ki ga opravlja po pogodbi. V nekaterih dejavnostih, v trgovini in prevozništvu, se zaposluje delavke in delavce samo s krajšim delovnim časom (gl. Kanjuo-Mrčela in Ignjatovič, 2018). Podjetja so ugotovila, da lahko iz delavke ali delavca

5 Med agencijskimi delavci so zaposlitve za nedoločen čas prestopile polovični prag leta 2015 in se dvignile na skoraj $70 \%$ leta 2018. Ta trend je spodbudila reforma leta 2013, ker jih je izvzela iz omejitve, da podjetje lahko najame samo $25 \%$ agencijskih delavcev, pa tudi "pravna praznina", ki jo je povzročila reforma, zaradi katere so redno zaposleni stroškovno cenejši od zaposlenih za določen čas, če so zaposleni manj kot eno leto (več o tem gl. Breznik, 2018). Zaposlitve s krajšim delovnim časom so bile med agencijskimi delavci ves čas redke, leta 2018 le $5 \%$. 
izčrpajo enako količino dela v manj kot osmih urah, plačajo pa ga manj kot za polni delovni čas. Zato zaposlujejo po več sto delavcev samo za krajši delovni čas, kar je silno naključje, da bi prav vsi hoteli delati krajši čas. Ob vseh naključjih nas zato ne bo presenetilo, da se je zaposlovanje te vrste najbolj povečalo v času gospodarske ekspanzije. Rast profitov je vzbudila še večji pohlep, zato se je ta delež precej povečal ravno v času gospodarske ekspanzije. Če je zaposlitev s krajšim delovnim časom sklenjena proti volji delavke ali delavca in obstajajo pogoji za zaposlitev za polni delovni čas, je pogodba zelo očitno pravno neustrezna in nezakonita, ker samo pogodba za polni delovni čas zagotavlja minimalni življenjski dohodek in varno starost. Če bi bili natančni, bi "neprostovoljno zaposlitev s krajšim delovnim časom» morali šteti za neformalno delo kot nekakšno »vsiljeno podzaposlenost«.

Druga spremenljivka je dohodek pod $60 \%$ povprečne plače, ki smo jo vzeli kot merilo za revne delavce. Ta dohodek smo merili ločeno pri standardno in nestandardno zaposlenih. Delež revnih delavcev med standardno zaposlenimi se je zmanjšal za polovico, na 5,7\%. K temu je prispevalo zvišanje minimalne plače za skoraj 23\% leta 2010 in izvzem nekaterih dodatkov iz minimalne plače leta 2015. Lahko pričakujemo, da se bo število skoraj 37 tisoč revnih delavcev med standardno zaposlenimi, kolikor smo jih izmerili leta 2018, še naprej zniževalo, ker so bili leta 2020 izvzeti iz minimalne plače vsi dodatki in ker se bo minimalna plača dodatno zvišala tudi leta 2021, ko bo po novi formuli presegla minimalne življenjske stroške za $20 \%$.

Tega pa ne moremo trditi za revne nestandardne delavce med zaposlenimi za določen čas, tistimi s krajšim delovnim časom in agencijskimi delavci, katerih delež se iz leta v leto prej ko ne povečuje, če opazujemo absolutne številke. Če zanemarimo nihanja iz leto v leto, njihov delež predstavlja približno tretjino vseh delavk in delavcev iz skupin, ki smo jih vključili v meritev. Zadnje leto 2018 je bilo "revnih« v teh skupinah okoli 40 tisoč oseb.

Spomnimo se, da smo neformalno delo definirali kot vsako plačano delo, ki ni prijavljeno državi z namenom, da se pogodbena partnerja izogneta plačilu (vseh ali dela) davkov in socialnih zavarovanj, pa tudi delovnopravnemu varstvu. Vendar pa mora biti to delo v vseh drugih vidikih zakonito, se pravi, ne sme biti delo v proizvodnji in trgovini prepovedanih blag (denimo z drogami) na eni strani, na drugi pa ne sme biti delo $v$ nedenarni recipročni družbeni menjavi. V podatkovni bazi smo identificirali dve večji skupini, ki kot obliki prikrite zaposlitve ustrezata taki definiciji: študentsko delo in navidezno samozaposleni.

Študentsko delo je občasno delo dijakinj in dijakov, študentk in študentov, ki vsaj pravno formalno redno študirajo. Stroški študentskega dela so se sicer močno zvišali leta 2015, ko mora honorar za študentsko delo vključevati plačilo socialnih prispevkov ter posebne dajatve za študentsko organizacijo in štipendijski sklad. Odtlej se študentsko delo šteje v pokojninsko 
dobo, če doseže dohodek $60 \%$ povprečne mesečne plače (kar je, mimogrede, več kot znaša minimalna plača). Toda s perspektive kapitala je študentsko delo še vedno cenejše kakor redne zaposlitve, zato je bila vladna kampanja "vsako delo šteje $v$ resnici slab alibi za prikrito zaposlovanje študentov. Zdrav razum pravi, da je prva dolžnost študentov učenje, toda razpredelnica kaže nasprotna dejstva. Vse obdobje se je delež študentov, ki opravljajo več kot 20 ur na teden (kar presega pojem občasnega dela), gibalo okoli $70 \%$ vseh, ki so opravljali študentsko delo. ${ }^{6}$ Leta 2017 , denimo, je 20 in več ur na teden delalo kar 20.293 študentk in študentov, med katerimi je tretjina (10.127 študentov) delala več kot 36 ur na teden. Skratka, tretjina vseh študentskih del je prikritih zaposlitev za polovični delovni čas, tretjina pa prikritih zaposlitev za polni delovni čas.

Druga skupina, ki smo jo identificirali v podatkovni bazi, so navidezno samozaposleni. Od leta 2012 ANP vsebuje dodatni vprašanji, ki lahko nakazujeta obstoj navideznih samozaposlitev. Samozaposlene, ki ne zaposlujejo delavcev, sprašujeta, ali »delajo pretežno le za eno stranko« in ali »večinoma delajo v prostorih te stranke«. Status osebe in ti okoliščini naj bi nakazovali, da samozaposlena oseba dela po pogodbi civilnega prava, vendar so okoliščine, v katerih opravlja delo, podobne delovnemu razmerju. To pomeni, da samo44 zaposleni opravlja delo sam, za plačilo in nepretrgoma, po navodilih in pod nadzorom delodajalca in pogosto kar $\mathrm{v}$ prostorih delodajalca $\mathrm{z}$ njegovimi delovnimi orodji. Za take primere Zakon o delovnih razmerjih določa, da se ne sme sklepati pogodb civilnega prava, temveč pogodba o zaposlitvi. Tisti, ki vseeno delajo na podlagi pogodb civilnega prava, so zato dobili ime "navidezno samozaposleni« (ang. bogus self-employed) in jih je mogoče najti med zavarovalniškimi agenti, novinarji, šoferji in celo po industrijskih obratih. Enako kot pri študentskem delu delodajalec "navidezno samozaposelnim ni dolžan zagotavljati dopusta, plačevati nadomestila plače med dopustom in bolniško odsotnostjo, regresa za letni dopust, povračila stroškov v zvezi z delom, ni dolžan upoštevati omejitev delovnega časa in z njimi lahko prekine sodelovanje praktično čez noč, brez odpovednih rokov in odpravnin.

Če zanemarimo manjša nihanja, se po letu 2012 število navidezno samozaposlenih ves čas zvišuje in je ob zadnji meritvi leta 2019 vključevalo okoli 12 tisoč oseb (leto prej celo 14 tisoč). Razpredelnica tudi kaže, da nova pooblastila Inšpektorata za delo, ki od leta 2017 lahko zahteva od podjetja, da z navidezno samozaposlenim sklene delovno razmerje, niso imela posebnega vpliva na njihovo zmanjšanje - če zanemarimo precejšnja letna nihanja, se povprečno število le-teh ni spremenilo.

6 Po podatkih SURS je bilo v šolskih letih 2017/18 in 2018/19 okoli 150.000 redno vpisanih dijakov in študentov, od tega polovica dijakov in polovica študentov. Ker študentsko delo v glavnem opravljajo študenti, lahko približno ocenimo (če naše podatke o študentskem delu prenesemo na približek 75.000 študentov), da je okoli $27 \%$ študentov prikrito zaposlenih. 
Obliki neformalnega dela, kot smo ju definirali, predstavljata okoli $4 \%$ vseh, ki smo jih vključili v prikaz. Vendar nista edini; kot sva že omenili, je treba šteti za neformalno delo tudi »neprostovoljno delo s krajšim delovnim časom».

\section{Sklep}

Pregled podatkov o zaposlovanju v obdobju 2005-2019, kot jih prikazuje ANP, kaže na veliko konjunkturno povečanje standardnih zaposlitev v zadnjem letu. Vendar se pokaže nekoliko drugačna podoba, če primerjamo povprečne deleže $\mathrm{v}$ obdobjih gospodarske recesije in ekspanzije. Tako vidimo, da se je povečal delež nestandardnih oblik dela, ki smo jih zajeli v primerjavo (vključujoč zaposlene za določen čas, s krajšim delovnim časom, agencijsko delo, študentsko delo in samozaposlovanje).

Iz teh primerjav lahko ugotovimo, da gospodarski obrat ni prispeval $\mathrm{k}$ zmanjšanju nestandardnega zaposlovanja. Nasprotno, gospodarska ekspanzija po letu 2014 je, kot je videti, še spodbudila zaposlovanje nestandardnih delavcev (predvsem za krajši delovni čas, agencijskih delavcev in samozaposlenih). Vrh tega je treba tudi ugotoviti, da reforme in zakonske spremembe, katerih namen je bil omejiti nestandardno delo (reforma leta 2013, višji stroški dela za študentsko delo, nova pooblastila Inšpektorata za delo glede navidezno samozaposlenih), zelo verjetno niso uspele obrniti trendov.

$\mathrm{V}$ analizo smo vpeljali razliko med nestandardnim in prekarnim delom, da bi identificirali razširjenost zaposlitev, ki jih zaznamujeta nizek dohodek in neprostovoljnost. Neprostovoljnost smo merili pri zaposlenih za določen čas in s krajšim delovnim časom, od katerih več kot polovica dela v teh oblikah neprostovoljno. Pri drugem kriteriju za prekarnost zaposlitve, ki se nanaša na nizke dohodke, dobrih $10 \%$ standardno in nestandardno zaposlenih prejema plačo, nižjo od $60 \%$ povprečne neto plače. Toda medtem ko se število revnih standardno zaposlenih delavcev postopoma znižuje, se število revnih nestandardno zaposlenih delavcev zvišuje sorazmerno s širjenjem nestandardnega zaposlovanja.

Razgrnitve segmentacije nestandardnega dela s tem še nismo zaključili. $\mathrm{V}$ pretresu statističnih podatkov smo identificirali še neformalne zaposlitve: prikriti zaposlitvi (navidezno samozaposlene, študentsko delo z več kot 20 urami na teden) in "vsiljeno podzaposlenost (neprostovoljno zaposlitev s krajšim delovnim časom). Ta skupina predstavlja od 5 do $7 \%$ vseh standardno in nestandardno zaposlenih, ki smo jih vključili v predstavitev. Medtem ko se je obseg prikritih zaposlitev med študentskim delom ves čas gibal na približno isti ravni (okoli dve tretjini), pa navidezno samozaposlovanje in »vsiljena podzaposlenost» naraščata.

Prekarnost in prekarno delo se morda res nista uspela razviti v teoretska 
koncepta (Breznik, 2018), vendar sta obrnila na glavo gledišče, ki ga je zasedla razprava o fleksibilnosti. Kot taka sta pomagala usmeriti pozornost na pavperizacijo delavstva in na širše procese destandardizacije, prekarizacije in deformalizacije zaposlitev. Pretres statističnih podatkov je opozoril tudi na previdnost pri operacionalizaciji prekarnega dela (v Barnierjevem pomenu), ki mora pri definiciji kazalnikov upoštevati specifičen družbeni kontekst (prag tveganja revščine, delovnopravno varstvo, značilnosti produkcijskih procesov, če naštejemo samo nekatere). Taka analiza je pogoj, da za t.i. procesi fleksibilizacije delovne sile razgrnemo prikrite procese destandardizacije, prekarizacije in deformalizacije zaposlitev. Oblike neformalnega dela so od vseh najbolj zaskrbljujoče, ker prinašajo nezadržno erozijo delovnopravnega varstva. Njihovo širjenje kaže tako na nepripravljenost nadzornih organov, da ukrepajo v primerih, ko se delavke in delavci znajdejo v položaju brezpravnosti, kakor tudi na toleranco okolja do takih praks. Najin pregled statističnih podatkov se sklene s koncem cikla gospodarske ekspanzije 2014-2019, zato lahko pričakujemo, da bo v naslednjih letih epidemija virusa covid-19 in zaostreni gospodarski pogoji pripraven alibi za nadaljnjo erozijo delovnopravnega varstva.

\section{LITERATURA}

Althusser, Louis (1980): Ideologija in ideološki aparati države. Zoja Skušek Močnik (ur.), Ideologija in estetski učinek, Ljubljana: Cankarjeva založba.

Bair, Jennifer in Marion Werner (2015): Global Production and Uneven Development: When Bringing Labour in isn't Enough. Kirsty Newsome, Phil Taylor, Jennifer Bair in Al Rainnie (ur.), Putting Labour at its Place, London: Palgrave.

Bembič, Branko (2018): Nestandardno zaposlovanje, prekarizacija in organizirano delo v Sloveniji. V: Miroslav Stanojević in Sašo Furlan (ur.), (Ne)dostojno delo: prekarizacija standardnega in nestandardnega zaposlovanja v Sloveniji, 52-85. Ljubljana: Fakulteta za družbene vede, Založba FDV.

Bologna, Sergio (2007): Ceti medi senza futuro? Rim: Derive Approdi.

Boltanski, Luc in Ėve Chiapello (1999): Le nouvel esprit du capitalisme, Pariz: Gallimard.

Bourdieu, Pierre (1998): La précarite est aujourd'hui partout. V: Pierre Bourdieu, Contre-feux, Pariz: Raisons d'Agir.

Braverman, Harry (1974): Labor and Monopoly Capital, New York: Monthly Review Press.

Breznik, Maja (2018): Agencijski delavci. V: Miroslav Stanojević in Sašo Furlan (ur.), (Ne)dostojno delo: prekarizacija standardnega in nestandardnega zaposlovanja v Sloveniji, 160-179. Ljubljana: Fakulteta za družbene vede, Založba FDV.

Castel, Robert (2003): From manual workers to wage laborers: transformation of the social question. New Brunswick, New Jersey: Transaction Publishers (fran. Les métamorphoses de la question sociale, 1996).

Hürtgen, Stefanie (2019): Mrežna množična produkcija, novi transnacionalni taylorizem in družbeno-prostorska segmentacija v globalni in evropski elektronski 
industriji. V: Ana Podvršič in Maja Breznik (ur.), Verige globalnega kapitalizma, Ljubljana: Založba Sophia.

Husson, Michel (2015): Teorija o dolgih valovih in kriza kapitalizma. V: Ernest Mandel (ur.), Dolgi valovi kapitalističnega razvoja, Ljubljana: Založba Sophia.

Kanjuo-Mrčela, Aleksandra in Miroljub Ignjatović (2018): Inovativno o prekarnosti? V: Miroslav Stanojević in Sašo Furlan (ur.), (Ne)dostojno delo: prekarizacija standardnega in nestandardnega zaposlovanja v Sloveniji, 107-129. Ljubljana: Založba FDV

Kalleberg, Arne (2011): Good jobs, bad jobs: the rise of polarized and precarious employment system in the United States, 1970s-2000s. New York: Russell Sage Foundation.

Keller, Berndt in Hartmut Seifert (2013): Atypical employment in Germany. Forms, development, patterns. Transfer 19 (4): 457-474.

Kretsos, Lefteris in Ilias Livanos (2016): »The extent and determinants of precarious employment in Europe«, International Journal of Manpower 37 (1): 25-43.

Milberg, William in Deborah Winkler (2013): Outsourcing Economics: Global Value Chains in Capitalist Development. New York: Cambridge University Press.

Munck, Ronaldo (2013): The Precariat: a view from the South. Third World Quarterly 34 (5): 747-762.

Podvršič, Ana in Maja Breznik (ur.) (2019): Verige globalnega kapitalizma, Ljubljana: Založba Sophia.

Portes, Alejandro in Saskia Sassen-Koob (1987): Making It Underground: Comparative Material on the Informal Sector in Western Market Economies. American Journal of Sociology 83 (1): 30-61.

Pulignano, Valeria, Paul Stewart, Andy Danford in Mike Richardson (ur.) (2008): Flexibility at Work. Critical Developments in the International Automobile Industry. London: Palgrave Macmillan.

Savage, Mike, Fiona Devine, Niall Cunningham, Mark Taylor, Yaojun Li, Johs. Hjellbrekke, Brigitte Le Roux, Sam Friedman in Andrew Miles (2013): A New Model of Social Class: Findings from the BBC's Great British Class Survey Experiment, Sociology 47 (2): 219-250

Siegmann, Karin Astrid in Freek Schiphorst (2016): Understanding the globalizing precariat: From informal sector to precarious work. Progress in Development Studies 16 (2): 111-123.

Smichowski, Bruno, Cédric Durand in Steven Knauss (2019): Vključevanje v globalne vrednostne verige in raznolični razvojni vzorci. V: Ana Podvršič in Maja Breznik (ur.), Verige globalnega kapitalizma, Ljubljana: Založba Sophia.

Standing, Guy (2008): Economic insecurity and global casualization: Threat or promise? Social Indicators Research 88 (1): 15-30.

Standing, Guy (2009): Work after Globalization. Cheltenham: Edward Elgar.

Standing, Guy (2011): The Precariat, The New Dangerous Class. London: Bloomsbury Academic.

Stanojević, Miroslav in Sašo Furlan (2018): Uvod: dostojno delo za vse? V: Stanojević, Miroslav in Sašo Furlan (ur.). (Ne)dostojno delo: prekarizacija standardnega in nestandardnega zaposlovanja v Sloveniji, 5-24. Ljubljana: Založba FDV. 
Stropnik, Nada, Matej Gregorič, Mojca Gabrijelčič Blenkuš, Monika Robnik in Ajda Švab (2017): Minimalni življenjski stroški. Ljubljana; Inštitut za ekonomska raziskovanja.

Vodopivec, Matija, Suzana Laporšek in Milan Vodopivec (2016): Levelling the Playing Field: The Effects of Slovenia's 2013 Labour Market Reform. IZA Discussion paper No. 9783.

Vosko, Leah F. (2010): Managing the Margins: Gender, Citizenship and the International Regulation of Precarious Employment. Oxford: Oxford University Press.

Williams, Colin C. in Jan Windebank (1989): Informal Employment in the Advanced Economies. London: Routledge.

Williams, Colin C. in Mark A. Lansky (2013): Informal employment in developed and developing economies: Perspectives and policy responses, International Labour Review 152 (3-4): 355-380.

Williams, Colin C. in Frédéric Lapeyre (2017): Dependent self-employment: Trends, challenges and policy responses in the EU, Ženeva: International Labour Organization.

Womack, James P., Daniel T. Jones and Daniel Roos (1990): The Machine That Changed the World: Based on the Massachusetts Institute of Technology 5-Million Dollar 5-Year Study on the Future of the Automobile. New York: Rawson Associates.

48 Wood, Stephen (1989): The Transformation of Work. London: Unwin Hyman.

Wright, Erik Olin (2016): Is the Precariat a Class? Global Labour Journal 7 (2): 123135.

\section{VIRI}

Eurofound (2016): Exploring the fraudulent contracting of work in the European Union, Luxembourg: Publications Office of the European Union.

Evropski parlament, Komisija za zaposlovanje in socialne zadeve (2016): Precarious Employment in Europe: Patterns, Trends and Policy Strategies, maj 2016.

Mednarodna organizacija dela (2016): Non-standard employment around the world: Understanding challenges, shaping prospects, Ženeva: International Labour Office.

OECD (2015): In It Together: Why Less Inequality Benefits All. V: OECD, Non-standard work, job polarisation and inequality, 4. poglavje. Paris: OECD Publishing.

SURS (2005-2018). Anketa o delovni sili/Aktivno in neaktivno prebivalstvo (mikropodatki). Ljubljana: SURS.

UMAR in MDDSZ (2015): Drugo poročilo Delovne skupine za spremljanje učinkov sprememb v regulaciji trga dela (maj 2015). Ljubljana: Urad za makroekonomske raziskave in razvoj.

UMAR (2016): Poročilo o razvoju 2016. Ljubljana: Urad za makroekonomske raziskave in razvoj. 